\title{
Erratum to: Shlomo Melmed: The Pituitary
}

\section{Academic Press-Elsevier, III edition, 731 pages, 4 sections and 21 chapters}

\section{Ezio Ghigo}

Published online: 22 January 2012

(C) Springer Science+Business Media, LLC 2012

Erratum to: Endocrine

DOI 10.1007/s12020-011-9546-2

In the title of the original publication, which appeared in the February issue (volume 41, issue 1), "4 chapters" should read "4 sections and 21 chapters."

The online version of the original article can be found under doi:10.1007/s12020-011-9546-2.

E. Ghigo $(\bowtie)$

Department of Medicine, University of Turin, Turin, Italy

e-mail: ezio.ghigo@unito.it 